\title{
Könyvbemutató-előadás a Regionális világrend: transzregionalizmus, regionális integráció és regionális együttmüködések Európában és Ázsiában címú tanulmánykötetről
}

Alexei D. Voskressenski - Koller Boglárka eds.: The Regional World Order: Transregionalism, Regional Integration and Regional

Projects across Europe and Asia, Lexington Books, USA, 2019.

Nemzeti Közszolgálati Egyetem, Államtudományi és Nemzetközi Tanulmányok Kar

2019. december 17.

Book Review on the volume The Regional World Order:

Transregionalism, Regional Integration and Regional

Projects across Europe and Asia, edited by Alexei D. Voskressenski and Boglárka Koller

Időszerű a könyv. Régóta beszélünk, írunk arról, hogy a nehezen definiálható globalizációs szindróma vagy folyamat mellett, részben amiatt, a világban folyik egy erősödő fragmentációs, regionalizációs és lokalizációs folyamat. Ezek egymást nem zárják ki. Nincs ebben semmi új. A világban korábban is voltak globalizációs folyamatok, a Római Birodalomban Hispániától a Dunáig sestertiusszal lehetett fizetni, azután később fragmentálódott a rendszer. A világgazdaság történetének az első nagy globalizációs időszaka a 19. század végére-20. század elejére esett, amikor valóban létrejött egy multilaterális, globálisnak nevezhető világgazdasági és világkereskedelmi rendszer. A jogi 
technika más volt, mert egymáshoz kapcsolódó, kétoldalú kereskedelmi egyezményekkel teremtették meg azt a lényegében egységes szabályozási keretet, amelyet azután később, 1947-től egy multilaterális, tehát egy valóságosan többoldalú jogi szabályozás hozott létre. Multilaterálissá lett a legnagyobb kedvezményes elbánás, amelyet korábban kétoldalú megállapodásokban kötöttek ki. A magyar Corpus Jurisban megtaláljuk azt a nagyszámú, kétoldalú kereskedelmi és hajózási egyezményt, amelyek mindegyike biztosította a másik félnek a legnagyobb kedvezményes elbánást. Ez azután felborult, jött egy erőteljes fragmentációs szakasz - nevezetesen az első világháború. Majd a világgazdaság megpróbálta ismét rendbe szedni magát, de már nem volt sok ideje, mert 1929-től kezdve újabb gondok álltak elő. Később, 1947-ben létrejött a Bretton Woodsnak nevezett jogi keretrendszer, amely a kereskedelmi szabályozás terén egy valóságos multilaterális, nyitott, befogadó rendszert teremtett meg.

Ennek fényében döbbentem meg nagyon, hogy a kötet 186. oldalán Charles Ziegler tollából az a megállapítás szerepel, amely szerint a General Agreement on Tariffs and Trade (a továbbiakban: GATT) zárt regionalizmus volt, egy „fortress arrangement”, ami gátolta a globális gazdasági kapcsolatokat. A GATT mindennek a totális ellentéte volt. Az első perctől kezdve nyitott volt, annyira, hogy Csehszlovákiát és Lengyelországot is tagjai közé vette, bár ezt követően a Szovjetunió e két országot eltiltotta a részvételtől. A fejlődő országok az önállóvá válásuk, felszabadulásuk menetében folyamatosan léptek be a GATT-ba, jelenleg 164 tagja van, köztük Oroszország és Kína. A WTO tehát ma egy ténylegesen univerzális nemzetközi szervezet.

Egy másik félreértés, ami a könyvben megjelenik, hogy a WTO, a Kereskedelmi Világszervezet a GATT utódszervezete. Itt két probléma van. Egyrészt a GATT soha nem volt szervezet, hanem megállapodás. Most is az. Másrészt nincs utódja, mert ma is létezik. Nem szűnt meg. Utódja csak annak lehet, aki megszűnik. A GATT 1947 ma is hatályos a GATT 1994 részeként. A GATT 1994 több részből áll, mindenekelőtt az 1947-es szövegből. E szöveg ma is hatályos, ennek kapcsán fogunk például vitatkozni arról, hogy a brit kilépéssel összefüggésben milyen kérdéseket kell tisztázni ahhoz, hogy a megállapodás a multilaterális rendszer keretei közé is beilleszkedjék, megfeleljen a GATT XXIV. cikkében foglalt feltételeknek. Tehát semmi nem lépett a GATT helyébe, de a rendszer kibővült. És a GATT 1994 - ahogy most nevezzük - a kardinális, központi eleme a lényegesen kibővült rendszernek és a számos kapcsolódó megállapodásnak, a szolgáltatáskereskedelemtől a szellemi alkotásokig. Ezt csak azért teszem szóvá, mert nem tudok magyarázatot találni arra, hogy hogyan lehet zárt, fortress arrangementnek nevezni a világ legnyitottabb és legbefogadóbb multilaterális kereskedelmi rendszerét.

Aminek persze tudjuk, vannak komoly problémái. Például nem fejlődik. 1995-ben még hatalmasat lépett előre, de most már legalább 15 éve nem mozdul előre. Ez az egyik korántsem egyetlen - oka annak - és erről szól a könyv -, hogy megindul a világkereskedelmi szabályozás szerkezetének a regionalizálódása. Egymás után jönnek létre a regionális és kétoldalú kereskedelmi megállapodások, amelyeket szabadkereskedelmi megállapodásoknak, FTA-nek (Free Trade Agreement) vagy preferenciális megállapodásoknak, PTA-nek, (Preferential Trade Agreement) nevezünk, mivel e megállapodásokban a felek az általánostól eltérő, preferenciális elbánást biztosítanak egymásnak. Ezért kell különbséget tenni a favour és a preference között, mert nem ugyanazt jelentik. A favour a (legnagyobb) kedvezmény, amit mindenki megkap, aki a multilaterális 
rendszer részese, a preference pedig az, amit csak külön kétoldalú vagy többoldalú (regionális) kereskedelmi megállapodás alapján lehet megszerezni. A ma már leggyakrabban használt elnevezés az RTA (Regional Trade Agreement). Számuk rohamosan nő és ez egyszerre oka és következménye a fragmentációnak, a kisebb, jórészt regionális egységek létrejöttének.

Az első generációs RTA-k megelégedtek a kereskedelmi akadályok lebontásával. Később világossá vált, hogy ha a kereskedelem akadályait eltörlik, akkor egyenlő versenyfeltételeket is kell teremteni, például az állami támogatásokat szabályozó előírások területén, és közelíteni kell a legkülönbözőbb védelmi szabályozásokat is, illetve szükség van a különböző regulációk, szabályozások harmonizációjára. Ez lesz a nagy vita az elkövetkezendő 11 hónapban az Európai Unió és az Egyesült Királyság között. Tisztázni kell majd, mit értenek a felek a level playing field alatt, és létre kell hozni valamilyen szintű szabályozási harmonizációt. Ez az, amit a britek kevésbé akarnak, különös tekintettel arra, hogy választaniuk kell majd az európai és az amerikai szabályozások között. A szabadkereskedelmi megállapodásoknak ma már egyre szélesebb regulációs tartalmuk is van. Jól bemutatja a kötet, hogy ezen a területen óriási különbségek vannak a különböző regionális típusú szabályozások között.

A tanulmánykötet nagy erényének tartom, hogy a témát újszerűen közelíti meg. Megjelenít egy új kategóriát, amit transzregionális kapcsolatnak nevez, ahol nem jelennek meg a régiók közötti kapcsolatok formális, jogi elemei, szemben az intézményi formát öltő interregionális kapcsolatokkal. Utóbbira lehet példa az Európai Unió és a MERCOSUR közötti megállapodás - ha létrejön, ami egyre kevéssé valószínú. Ami az EU és az ASEAN közötti megállapodást illeti, az Unió döntése az volt, hogy először az egyes ASEAN-tagállamokkal kötünk megállapodást. Ezek egy része - például Szingapúrral, Vietnámmal - már létre is jött. Amikor mindegyikkel megkötöttük, akkor jön a geopolitikai és kereskedelmi szabályozási dilemma, hogy hogyan lehet ezt a hálót egy egységes, régiók közötti megállapodássá átformálni. Nem tartunk még itt, azt sem tudjuk, hogy mikor kerül erre sor, de a kötet által adott tudományos elemzések segítik ezt a munkát.

Nehezebb kérdés, miként alakuljanak a kapcsolatok az Európai Unió és az Eurázsiai Gazdasági Unió között. Az utóbbi, különböző átmeneti formációk után eljutott a vámunió szintjére, van intézményrendszere is, és meg tud jelenni nemzetközi szinten. Elvileg tehát képes régiók közötti megállapodást létrehozni. A hazai közbeszédben ezzel kapcsolatban újabban sok, politikai szempontokra épülő, erősen naiv elképzelés van jelen, ezért érdemes hivatkozni bizonyos alapvető tényekre. Az Eurázsiai Gazdasági Uniónak a nominális alapon számított teljes GDP-je annyi, vagy kicsit kevesebb, mint Olaszországé. A vásárlóerő-paritáson számolt GDP-je ennél jóval több. A nominális GDP 1,9, a vásárlóerő-paritáson számított 4,4-4,7. Nagy különbség van tehát a kettő között, aminek az az oka, hogy rendkívül alacsony életszínvonalú országokról van szó, ráadásul a nominális GDP volatilis, mert az árfolyammozgások - döntően az orosz rubel mozgása - a nominális GDP-t erősen befolyásolták. Az Eurázsiai Gazdasági Unió GDP-jének 87\%-át Oroszország adja. A költségvetése az Európai Unió költségvetésének az 1\%o-e. Az Afrikai Unió költségvetése az Eurázsiai Gazdasági Unió költségvetésének az ötszöröse. Tehát van még fejlődési lehetőség. Ennél még lényegesebb, hogy Oroszország valójában kevéssé érdekelt egy klasszikus, hagyományos, az ipari termékek kivitelét megkönnyítő szabadkereskedelmi megállapodás megkötésében. A GATT-ba elég hosszú idő 
után és nem kis nehézségek mellett belépett, bár a nehézségek nem szűntek meg teljesen. Az energiakivitelhez, a földgáz- és kőolajkivitelhez nincs szükség szabadkereskedelemre; akinek szüksége van olajra és földgázra, az meg fogja azt venni. Az orosz gazdaság ereje két tényezőn nyugszik: az egyik az energia, a másik a fegyvereladás. Aki fegyvert vesz, az nem vet ki rá vámot. Az a lényeg, hogy a legkorszerúbb, leghatékonyabb, és lehetőleg - gyakran - a legdrágább fegyverrendszereket vegye meg. Tehát ezek a termékek nem esnek a hagyományos kereskedelmi szabályozás körébe.

Jó dolog, hogy az Eurázsiai Gazdasági Unió létrejött, de azok az álmok, hogy mi majd ehhez fogunk kapcsolódni, hiszen a jövő a hatalmas ázsiai szárazföldé, megalapozatlanok. Hogy az óceánokon vagy a szárazföldön van-e a dominancia forrása, az változik. Kína ezt a kérdést nem kívánja eldönteni, mert a One Belt, One Road-ot megcsinálja a szárazföldön is, és a tengeren is, mind Közép-Ázsián, mind pedig az Indiai-óceánon keresztül, és így érkezik a mi számunkra fontosnak tűnő Pireuszba, hiszen onnan fognak majd a kínai áruk tömegesen a Belgrád-Budapest gyorsvasúton keresztül olcsón és gyorsan megérkezni.

Annak idején 1947-ben, amikor létrehozták a multilaterális rendszert, gondoltak már arra, hogy a rendszer ugyan meghirdeti az egyenlő elbánás elvét, amelyet a zseniális jogi technika, a legnagyobb kedvezményes elbánás fog megvalósítani, de a kivételeket is meg kell teremteni. A fő szabály a legnagyobb kedvezmény elve, de a XXIV. cikkben már megjelennek a kivételek, a szabadkereskedelem és a vámunió. Majd néhány évtized után állt elő az igény, hogy a fejlődő országoknak preferenciákat kell adni, és így került sor a GSP, az általános vámpreferenciák rendszerének a bevezetésére.

A fragmentáció, a regionalizáció és a lokalizáció régóta tart, de az elmúlt időben felerősödött. Erre utal a világkereskedelem, a beruházások és a tőkemozgások alakulása. A világkereskedelem évek óta nem nő gyorsabban, mint a világgazdaság, főleg az áruforgalom területén. A kereskedelem szerkezete is átalakul, mert az áruforgalom relatíve csökken. Kiderült, hogy a tengeri fuvarozás a klímaváltozás szempontjából a legkártékonyabb, mert a „lábnyoma” a tengeri hajózásnak a legnagyobb. A szabadkereskedelem jó dolog, de a kereskedelem lábnyomát mérsékelni kell. Ha regionalizáljuk a kapcsolatok egész rendszerét, hálózatát, akkor óhatatlanul a közelebbi beszerzési és értékesítési lehetőségeket keressük. A szabadkereskedelmi megállapodások maguk is ezt a regionalizációt képviselik, egyszerre okai és következményei tehát ennek az átalakulásnak.

A szabadkereskedelmi megállapodások létrehozásának négy oka, illetve feltétele van. Az első, a felek közötti kereskedelmi és gazdasági kapcsolatok intenzitása. A második, hogy valamelyest hasonlóak legyenek a gazdasági fejlettségi szintek. Ez nincs mindig így, mert például az ASEAN-ban jelen van a világ leggazdagabb országa, Brunei, és a tagok között vannak a világ legszegényebb országai, Laosz, Kambodzsa és Mianmar is. Mégis ez az a regionális gazdasági integráció, amely az Európai Unió után eddig a legmagasabb szintre jutott. További feltétel, hogy a gazdaságfilozófiák és ennek megfelelően a gazdaságpolitikák között minimális hasonlóság álljon fenn. A gyakorlatban ez azt jelenti, hogy a felek mindegyike részese legyen a GATT-nak, mert akkor legalább a fó elveket elfogadja. Kínával sokan akarnak regionális megállapodást kötni, és jónéhányan kötöttek is már. A jövő egyik fő kérdése, hogy a kínai dominancia milyen regionális rendszereken keresztül fog majd érvényesülni, elsősorban az Indiai-, a Csendes-óceánon és Közép-Ázsiában. Ugyanakkor Kína a GATT-ban még mindig - egyesek szerint egyre 
inkább - idegen test, és ez a problémák egyik fő forrása. A 70 éve jól múködő rendszer szétveréséért nem Trump az egyetlen felelős. A gondok egyik fő oka, hogy Kína soha nem tartotta magára nézve teljes mértékben kötelezőnek a GATT fő elveit. Ahol a pénzügyi források allokálása egy olyan bankrendszer kezében van, amelyet az egyetlen párt politikai bizottsága irányít, ott nehéz a GATT által tételezett piacgazdaságról beszélni. $\mathrm{Az}$ állami tulajdonú vállalatoknak a meghatározó szerepe, a szellemi tulajdonnal kapcsolatos problémák szintén alapot adnak az amerikai, sőt az erősödő európai panaszoknak is.

A negyedik szempont az, hogy a felek milyen földrajzi távolságban vannak egymástól. Az egymáshoz közelebb lévő országok általában könnyebben hoznak létre regionális szövetséget és gazdasági integrációt akár szabadkereskedelem, akár vámunió formájában. A távolság számít - distance matters - szól a tétel. Majd kiderül a brit kilépés kapcsán, hogy tudja-e Ausztrália, Új-Zéland és az Egyesült Államok pótolni az Európai Uniót, ahova jelenleg a brit kivitel közel 50\%-a irányul és ahol a supply chainek nagy része in time deliveryt igényel. Ezt a jövő eldönti.

A könyv legnagyobb erénye, hogy felveti az alapkérdést. A biztonság vagy a gazdaság az első? És mi a szerepe a harmadiknak, az ideológiának? Ezt mostanában úgy nevezzük, hogy identitás. Mi ezek viszonya egymáshoz? Belép tehát a szabadkereskedelmi megállapodások rendszerébe a geopolitika. Egyrészt roncsol, szétver létező rendszereket, másrészt újakat épít. A geopolitikai érdekek mentén is alakulnak a GATT XXIV. cikkén alapuló szabadkereskedelmi megállapodások és/vagy vámuniók, és azok továbbfejlesztett változatai, amelyek már rég túl vannak az eredeti céljukon, kiterjednek a környezetvédelemre, a klímaváltozásra, az emberi jogokra és sok minden másra.

$\mathrm{Az}$ Európán kívüli regionális együttmüködések általában kevéssé foglalkoznak a jogi szerkezettel. Nem építenek ki intézményrendszert, nem teremtik meg a jogi viták eldöntésének mechanizmusát. Erősebb a biztonságpolitikai dimenzió. A jövő kérdése, hogy lépnek, vagy nem lépnek egy erőteljesebb intézményrendszer kialakítása felé. $\mathrm{Az}$ ASEAN például ebbe az irányba megy, és talán a NAFTA-t váltó USMCA is.

Európában is van arra példa, és erről is van egy kiváló tanulmány a kötetben, hogy olyan együttmúködés épül ki, ami nem kap intézményi keretet. A V4 jól múködik, és jelenleg nem is áll szándékunkban intézményi keretet létrehozni. A Visegrádi Együttmüködés egyre jobban jelen van. Először csak egy zavaró elem volt egyesek számára, de most már egy következő fázisban vagyunk, komoly tényezők lettünk. Nélkülünk - úgy tûnt legalábbis a legutóbbi hetekben - különlegesen fontos személyi döntéseket nem is nagyon lehet meghozni.

Azért fontos a biztonságnak és a gazdasági szabályozásnak a kapcsolatát elemezni, mert a multilaterális kereskedelmi rendszer lebontásának az egyik útja az, hogy a biztonságpolitika részben gazdasági, kereskedelmi érdekek közvetlen érvényesítésére, részben azok leplezésére szolgál. Ez a helyzet akkor, amikor a GATT XXI. cikkében foglalt nemzetbiztonsági kivételre hivatkozva történik az európai, mexikói, japán, kanadai acél és alumínium behozatal korlátozása. A nemzetbiztonsági kivétel vitarendezésre nehezen vihető, bár született egy döntés a Rosznyeft-ügyben orosz-ukrán viszonyban, amely szerint a kérdés elvileg lehet vitarendezés tárgya, de 2019. december 10-ével a vitarendezés lényegében megszűnt. Az Appellate Body a Fellebbviteli Testület tagok hiányában megszűnt, ami azt jelenti, hogy ha az elsőfokú paneldöntést valamelyik fél 
megfellebbezi, fellebbezési fórum híján nem lesz jogerős döntés, a fellebbezés a „semmibe megy” („appeal to the void”). Tehát az a rendszer, ami kialakult 1947 óta, 1995-ben megerősödött, és egész jól múködött, most megszűnni látszik.

Ami a regionális megállapodások vitarendezési eljárásait illeti, ezek is jelentős mértékben támaszkodnak a multilaterális szabályokra. Ha tehát nem lesz multilaterális rendszer, akkor a regionális rendszereknek a saját problémáikat is nehezebb lesz megoldaniuk. A kötet lényege, hogy multilaterális rendszer hiányában ki lehet-e építeni egy olyan világrendet, amelyikben már nincs univerzális multilaterális háttér, és valami újat építünk a helyébe. Felmerülhet például egy plurilaterális rendszer, amelyben sokan vannak, majdnem mindenki, de nem mindenki. Nincs benne például az Egyesült Államok. Ez nehéz ügy és veszélyes is, gondoljunk rögtön a politikai, geopolitikai következményekre. Európa kizárná a legszorosabb szövetségesét? A biztonsága őrét?

Az épülő világrend talán legfontosabb kérdése, hogy milyen mértékben fragmentálódik és regionalizálódik a világ, melyek lesznek ennek a geopolitikai, biztonsági, valamint gazdasági és kereskedelempolitikai következményei. A kötet erről szól, ezért érdemel különleges figyelmet és képvisel különleges értéket. Megállapításaival és következtetéseivel lehet egyetérteni vagy egyet nem érteni, de a szerzők hozzájárulása a jövőnket meghatározó fő folyamatok megértéséhez vitathatatlan.

\section{Felhasznált irodalom}

Voskressenski, Alexei D. - Koller, Boglárka eds. (2019): The Regional World Order: Transregionalism, Regional Integration and Regional Projects across Europe and Asia. Lanham - Boulder - New York - London, Lexington Books. 